OPEN ACCESS

Edited by:

Eytan Wine,

University of Alberta, Canada

Reviewed by:

Eleftheria Stamatios Roma,

University of Athens, Greece

Vaidotas Urbonas,

Vilnius University Children's

Hospital, Lithuania

*Correspondence:

Kaija-Leena Kolho

kaija-leena.kolho@helsinki.fi

Specialty section:

This article was submitted to

Pediatric Gastroenterology,

Hepatology and Nutrition,

a section of the journal

Frontiers in Pediatrics

Received: 30 October 2020

Accepted: 15 December 2020

Published: 13 January 2021

Citation:

Kolho K-L (2021) Therapeutic Drug

Monitoring and Outcome of Infliximab

Therapy in Pediatric Onset

Inflammatory Bowel Disease.

Front. Pediatr. 8:623689.

doi: 10.3389/fped.2020.623689

\section{Therapeutic Drug Monitoring and Outcome of Infliximab Therapy in Pediatric Onset Inflammatory Bowel Disease}

\author{
Kaija-Leena Kolho ${ }^{1,2 *}$ \\ ${ }^{1}$ Children's Hospital, Helsinki University Hospital and University of Helsinki, Helsinki, Finland, ${ }^{2}$ Faculty of Medicine and \\ Medical Technology, Tampere University, Tampere, Finland
}

Inflammatory bowel disease (IBD) with pediatric onset has become more prevalent during past decades. Thus, the number of patients with moderate to severe disease subtype treated with antagonists to tumor necrosis factor alpha (TNF $\alpha$ ) has concurrently risen. Most pediatric patients initially respond to these drugs but will need dose escalation during the first year of therapy. As pediatric data regarding therapeutic drug monitoring during therapy with TNF $\alpha$-blocker adalimumab are sparse, this review focuses on the literature on therapeutic drug monitoring of infliximab and how it may guide management.

Keywords: anti-TNF, children, Crohn disease, ulcerative colitis, unclassified colitis

\section{INTRODUCTION}

Infliximab, which is a monoclonal antibody to tumor necrosis factor alpha $(\mathrm{TNF} \alpha)$, has become the mainstay therapeutic agent for treating moderate to severe pediatric inflammatory bowel disease (PIBD). This is comparable with the management of adult IBD. The patent for infliximab expired in Europe in 2015 and nowadays there are on the market several biosimilars to the original drug Remicade (Janssen Biologics) $(1,2)$. So far, there are no safety alarms related to the use of biosimilars and the efficacy in clinical practice is comparable to the original drug (2). The access to the different drugs and their use varies between countries. Infliximab and its biosimilars are licensed for use in children who are at least 6 years of age and have moderate to severe Crohn disease or ulcerative colitis. Several countries, such as Finland, allow off-label use in younger children at the physicians' discretion. Induction phase of the drug covers 8 weeks and the three first doses are administered intravenously at week 0,2 , and 6 , and mostly as $5 \mathrm{mg} / \mathrm{kg}$. Maintenance phase and the fourth dose follow after 8 weeks (1-5). Most patients with PIBD, especially with Crohn disease, initially respond to infliximab therapy but will need dose escalation during the first year of therapy (6-8). This includes shortening of the interval and increasing the dose. To guide therapeutic decisions, the use of trough level measurementsof infliximab have emerged (9-12). In PIBD, the published reports on drug level monitoring mostly concern the use of the original drug and the use of biosimilars is less addressed. This review discusses use of infliximab trough level measurements in the management of PIBD. 


\section{Why Do Patients With Pediatric Onset Inflammatory Bowel Disease Treated With Infliximab Need Trough Level Measurements of the Drug?}

Induction of infliximab therapy results in responders in rapid improvement of clinical symptoms, blood and fecal inflammatory markers $(13,14)$, and even weight gain $(15,16)$. For example, the normalization of fecal calprotectin levels may occur already during the first 2 weeks of the therapy when response is complete (17). Perhaps unexpectedly, in partial responders the improvement in the objective markers of inflammation is only modest between therapy weeks 2 and $6(17-19)$. During the first year of therapy up to $80 \%$ of the pediatric patients may need therapy escalation and one third may eventually be judged as non-responders and need switching to other therapeutic drugs $(6-8,20)$. When non-response is timely detected and therapy adjusted accordingly, the therapeutic drug monitoring improves cost-effectiveness of the management $(21,22)$.

Most reports on infliximab trough levels in PIBD originate from single centers and are retrospective reports. Therefore, the number of included patients is limited, the timing of trough level measurements is variable, and in most studies, only samples taken during maintenance therapy are included. Table $\mathbf{1}$ summarizes some of the most recent studies with considerable number of patients with PIBD (23-31). The general conclusion from these studies is that in the group of patients with clinical remission or mild disease activity, the trough levels of infliximab are statistically significantly higher than in the group of patients with poor or unsatisfactory response. Also, the proportions of patients with undetectable or low levels of the drug are higher in the latter groups. However, the absolute values of the median (or mean) values are close to one another and there is significant overlap with the interquartile ranges of the values. In current clinical practice the target range is somewhat higher than in the early days of adopting the infliximab therapy in PIBD. There is no clear consensus of the target trough levels but levels above 3-5 $\mathrm{mg} / \mathrm{mL}$ are considered adequate (11). This applies to all disease subtypes, i.e., Crohn disease, ulcerative colitis and unclassified colitis (31-33). However, in acute severe colitis to reach these levels may need vigorous dosing probably due to increased clearance of the drug in active inflammation $(3,5)$. Notably, in perianal fistulazing disease the target level for best prediction of fistula healing may be as high as $12.7 \mathrm{mg} / \mathrm{mL}$ (34). Importantly, higher trough levels do not result in increased risk for infections or other adverse events (35). It is remarked that there is variability in the performance of the different assays for measurement of the drug levels hampering the comparison of absolute values in different settings (36). There are less data on the performance of the commercial assays when using biosimilars but according to our experience the results are comparable with infliximab and its biosimilars (20).

In studies on drug monitoring in PIBD, the grouping of the patients according to their therapeutic response is most often based on clinical remission, defined with PCDAI or PUCAI indices $(25,30)$. In the study by van Hoeve et al. $(27), 40$ patients underwent endoscopy after a median of 12.6 months and there were in total 87 time points for endoscopic data. In $54 \%$ of the visits, the patients were in endoscopic remission. In those children who were in remission, the median infliximab trough levels were significantly higher compared to those not in remission (Table 1).

In clinical practice, most have measured trough levels when the therapeutic response is not optimal or there has occurred an adverse event that might be related to the presence of drug antibodies and low trough levels. Although drug antibody formation is rare during first weeks of therapy $(18,37)$, there has been discussion whether trough levels should be measured already during induction. Suboptimal trough levels may guide therapy enhancement and in theory, adjusting the dosing early may prevent loss of response. If trough levels are suboptimal at week 6 to 8 , this may associate with inferior therapeutic response $(10,38)$ and increase the risk for antibody formation prior the first maintenance dose (fourth dose of the therapy). To avoid this, many clinics have started to monitor the trough level for the first time at week 6 to be able to enhance the therapy in due course when needed. Indeed, higher trough levels at the first dose of maintenance predicted sustained remission at 1 year (26). Recently, it was suggested that infliximab concentration of $\geq 29 \mu \mathrm{g} / \mathrm{ml}$ at infusion 2 and $\geq 18 \mu \mathrm{g} / \mathrm{ml}$ at infusion 3 was associated with improved outcomes (25) in infliximab-treated patients with PIBD.

When decisions on drug dosing are based on clinical data, inflammatory markers and drug levels, most pediatric patients need therapy adjustment compared to standard of care (39). One of the first studies reporting comparison of patients with PIBD followed up with proactive drug level monitoring and patients with standard care, concluded that there was a difference in the median values of the drug levels between these groups but no difference in the therapeutic outcomes (24). Thus, although in the current practice most aim to achieve higher trough levels to improve therapeutic response and to diminish loss of efficacy, the data on showing that this indeed results in better outcomes are sparse.

The mechanisms for the loss of response to infliximab therapy are not completely understood. Several hypotheses have been proposed including e.g., (1) drug antibody formation (2) a high inflammatory load of the disease and rapid turnover of the drug (3) development of an alternate inflammatory pathway. To avoid drug antibody formation, some favor combination therapy with immunosuppressants although this increases the risk of severe adverse events (40) and does not invariably protect from drug antibody formation (19). In young children, the clearance of infliximab has been estimated to be more rapid and to achieve target levels of the drug, higher doses around $10 \mathrm{mg} / \mathrm{kg}$ and shortening of the interval to $4-5$ weeks may be needed (41). A recent study summarized data from 215 patients with PIBD treated with infliximab and with trough level measurements during induction and maintenance. Regarding patients younger than 10 years of age, two thirds of the patients had trough levels below the target level at the start of the maintenance therapy. After one year of therapy, the dose requirements and risk to develop drug antibodies were higher in the group of young patients compared to the older 
TABLE 1 | Summary of the main studies included in the review.

\begin{tabular}{|c|c|c|c|c|c|}
\hline References & $\begin{array}{l}\text { No. of } \\
\text { patients }\end{array}$ & Age years & $\begin{array}{l}\text { Trough level } \\
\text { measurements }\end{array}$ & $\begin{array}{l}\text { Drug antibody } \\
\text { measurements }\end{array}$ & Results from trough level measurements \\
\hline $\begin{array}{l}\text { Naviglio et al. } \\
\text { (23) }\end{array}$ & $\begin{array}{l}49 \\
\text { Crohn } 34 \\
\text { UC } 15\end{array}$ & $\begin{array}{l}14 \text { median } \\
(\mathrm{IQR} 11.6- \\
16.2)\end{array}$ & $\begin{array}{l}n=\text { not available } \\
\text { at } \\
\text { week } 6,14,22,54\end{array}$ & $\begin{array}{l}\text { When IFX level }<1.5 \mathrm{mg} / \mathrm{mL} \\
10 \text { patients }(20.4 \%) \text { had low } \\
\text { levels and were positive for } \\
\text { drug antibodies }\end{array}$ & $\begin{array}{l}\text { at week } 6 \\
\text { In clinical remission median } 9.8 \mu \mathrm{g} / \mathrm{mL} \text { (IQR } 8.4 \text { to 12.6) } \\
\text { vs. } 7.1 \mu \mathrm{g} / \mathrm{mL} \text { (IQR } 4.7 \text { to } 9.8 \mu \mathrm{g} / \mathrm{mL} \text { ) in active disease } \\
\text { at week } 54 \\
\text { In clinical remission median } 6.1 \mu \mathrm{g} / \mathrm{mL} \text { (IQR 3.8-9.6) vs. } \\
1.4 \mu \mathrm{g} / \mathrm{mL}(\text { IQR } 0.35-2.8 \mu \mathrm{g} / \mathrm{mL} \text { ) in active disease }\end{array}$ \\
\hline $\begin{array}{l}\text { Lega et al. } \\
\text { (24) }\end{array}$ & $\begin{array}{l}83 \\
\text { Crohn } 76 \\
\text { UC } 7\end{array}$ & $\begin{array}{l}14 \\
\text { Median } \\
(\text { IQR 11-16) }\end{array}$ & $\begin{array}{l}n=243 \\
\text { during maintenance }\end{array}$ & $\begin{array}{l}25(30 \%) \text { positive for } \\
\text { drug antibodies }\end{array}$ & $\begin{array}{l}\text { In proactive monitoring group median } 9.1 \mu \mathrm{g} / \mathrm{mL} \text { (IQR } \\
6.2-13 \text { ) vs. } 5.4 \mu \mathrm{g} / \mathrm{mL} \text { (IQR } 1.7-10.8 \text { ) in the group of } \\
\text { standard care }\end{array}$ \\
\hline $\begin{array}{l}\text { Clarkston } \\
\text { et al. }(25)\end{array}$ & 72 & $\begin{array}{l}13 \text { mean } \\
(\mathrm{SD} \pm 4)\end{array}$ & $\begin{array}{l}n=\text { not available } \\
\text { during induction }\end{array}$ & None & $\begin{array}{l}\text { In clinical responders median } 27.8 \mu \mathrm{g} / \mathrm{ml} \text { (IQR19.5- 40) } \\
\text { at infusion } 2 \text { and } 14 \mu \mathrm{g} / \mathrm{ml}(\mathrm{IQR} 8.3-24) \text { at infusion } 3\end{array}$ \\
\hline $\begin{array}{l}\text { van Hoeve } \\
\text { et al. (26) }\end{array}$ & $\begin{array}{l}35 \\
\text { Crohn } 23 \\
\text { UC } 12\end{array}$ & $\begin{array}{l}12.7 \\
(I Q R \text { 10.2- } \\
14.6)\end{array}$ & $\begin{array}{l}n=35 \text { at week } 12 \\
\text { to } 14\end{array}$ & $\begin{array}{l}\text { In } 3 \text { with undetectable } \\
\text { trough levels but all negative }\end{array}$ & $\begin{array}{l}\text { Clinical 4.6mg/mL (IQR2.7) vs. } 1.5 \mathrm{mg} / \mathrm{mL} \text { (IQR 0.9-3.0), } \\
\text { biological } 4.6 \mathrm{mg} / \mathrm{mL} \text { (IQR 2.5-10.3) vs. } 2.6 \mathrm{mg} / \mathrm{mL} \text { (IQR } \\
0.3-3.2 \text { ) and combined clinical/biological remission } \\
6.0 \mathrm{mg} / \mathrm{mL}(\mathrm{IQR} 3.2-12.0 \text { ) vs. } 2.6 \mathrm{mg} / \mathrm{mL} \text { (IQR 1.1-3.2) at } \\
\text { week } 52 \text { compared to children not meeting these criteria } \\
\text { (all } P<0.002 \text { ) }\end{array}$ \\
\hline $\begin{array}{l}\text { van Hoeve } \\
\text { et al. (27) }\end{array}$ & $\begin{array}{l}52 \\
\text { Crohn } 33 \\
\text { UC } 19\end{array}$ & & $\begin{array}{l}n=686 \\
\text { during maintenance }\end{array}$ & & $\begin{array}{l}\text { In clinical, biological and endoscopic remission median } \\
\text { levels were } 5.2,5.7 \text { and } 6.5 \mu \mathrm{g} / \mathrm{mL} \text {, respectively, and } \\
\text { higher than in those not meeting these criteria } 4.2 \mu \mathrm{g} / \mathrm{mL} \\
\text { (IQR 2.6-6.7) } 3.7 \mathrm{mg} / \mathrm{L} \text { (IIQR 1.8-5.4) and } 1.2 \mathrm{mg} / \mathrm{L} \text { (IQR } \\
\text { 0.03-4.4; P = 0.01), respectively }\end{array}$ \\
\hline $\begin{array}{l}\text { Ungar et al. } \\
\text { (28) }\end{array}$ & $\begin{array}{l}63 \\
\text { Crohn } 50 \\
\text { UC } 13\end{array}$ & $\begin{array}{l}\text { median } 14 \\
(\text { IQR } 11.75- \\
\text { 16) }\end{array}$ & $\begin{array}{l}n=773 \text { during } \\
\text { induction and } \\
\text { maintenance ( } n \\
=682)\end{array}$ & $\begin{array}{l}\text { At week } 6 \text { and } 14 \text { median } \\
\text { levels of drug antibodies } \\
\text { higher in patients } \\
\text { discontinuing the therapy } \\
\text { during } 1 \text { year vs. patients } \\
\text { with ongoing therapy }\end{array}$ & $\begin{array}{l}\text { In clinical remission } 4.0 \mathrm{mg} / \mathrm{mL} \text { (IQR } 2.0-6.4) \text { vs. } 2.25 \\
\mathrm{mg} / \mathrm{mL} \text { (IQR 0.5-4.7; } \mathrm{p}<0.0001) \text { in clinically active } \\
\text { disease } \\
\text { Median levels at week } 2 \text { higher when in clinical } \\
\text { remission at week 14: } 12.8 \mathrm{mg} / \mathrm{mL}(\mathrm{IQR} 9.7-16.2) \text { in } \\
\text { clinical remission compared to } 7.6 \mathrm{mg} / \mathrm{mL} \text { (IQR } \\
2.1-12.9 \text { ) in clinically active disease }(P<0.02) \\
\text { Median levels at week } 6 \text { higher when in clinical } \\
\text { remission at week 14: } 8.4 \mathrm{mg} / \mathrm{mL},(I Q R ~ 6.9-17.0) \text { in } \\
\text { clinical remission vs. } 5.5 \mathrm{mg} / \mathrm{mL}(\mathrm{IQR} 0.27-12.3) \text { in } \\
\text { clinically active disease }(P<0.04)\end{array}$ \\
\hline $\begin{array}{l}\text { Merras- } \\
\text { Salmio and } \\
\text { Kolho (19) }\end{array}$ & $\begin{array}{l}145 \\
\text { Crohn } 101 \\
\text { UC } 32 \\
\text { IBDU } 12\end{array}$ & $\begin{array}{l}14.8 \text { median } \\
(\mathrm{IQR} 12.5- \\
16.0)\end{array}$ & $\begin{array}{l}n=475 \text { during } \\
\text { induction } \\
\text { and maintenance }\end{array}$ & $\begin{array}{l}208 \text { analyses } \\
\text { when IFX }<2.0 \mathrm{mg} / \mathrm{L}, 65 \% \\
\text { positive } \\
\text { when IFX }<0.2 \mathrm{mg} / \mathrm{L} \\
89 \% \text { positive }\end{array}$ & $\begin{array}{l}\text { In remission and/or ongoing therapy median } 3.7 \mathrm{mg} / \mathrm{L} \\
(\mathrm{IQR} 1.8-5.4) \mathrm{vs} .1 .2 \mathrm{mg} / \mathrm{L}(\mathrm{IQR} 0.05-4.4) \text { in the group } \\
\text { with loss of efficacy or no efficacy }\end{array}$ \\
\hline $\begin{array}{l}\text { Choi et al. } \\
\text { (29) }\end{array}$ & $\begin{array}{l}39 \\
\text { Crohn } 29 \\
\text { UC } 10\end{array}$ & $<19$ & $\begin{array}{l}n=99 \\
\text { during maintenance }\end{array}$ & $\begin{array}{l}\text { Drug antibodies } 0 / 16 \text { with } \\
\text { good response and } 7 / 23 \\
\text { with poor response }\end{array}$ & $\begin{array}{l}\text { In clinical remission levels higher than in those with poor } \\
\text { response median } 3.99 \mu \mathrm{g} / \mathrm{mL}(\mathrm{IQR}, 0.30-21.96) \mathrm{vs} \text {. } \\
0.88 \mu \mathrm{g} / \mathrm{mL}(\mathrm{IQR}, 0.00-6.80, \mathrm{p}=0.002)\end{array}$ \\
\hline $\begin{array}{l}\text { Rolandsdotter. } \\
\text { (30) }\end{array}$ & $\begin{array}{l}45 \\
\text { Crohn } 32 \\
\text { UC } 13\end{array}$ & $7-18$ & $\begin{array}{l}n=93 \\
\text { during maintenance }\end{array}$ & $\begin{array}{l}12 \text { samples with } \\
\text { undetectable trough levels } \\
\text { and all positive for } \\
\text { drug antibodies }\end{array}$ & $\begin{array}{l}\text { In clinical remission mean levels higher }(7.2 \mu \mathrm{g} / \mathrm{mL}) \\
\text { compared to active disease } 4.5 \mu \mathrm{g} / \mathrm{mL}(p<0.05)\end{array}$ \\
\hline $\begin{array}{l}\text { Deora et al. } \\
\text { (31) }\end{array}$ & $\begin{array}{l}73 \\
\text { Crohn } 52 \\
\text { UC } 18 \\
\text { IBDU } 3\end{array}$ & $\begin{array}{l}\text { median } 16.12 \\
(\mathrm{IQR} 14.34- \\
17.91)\end{array}$ & $\begin{array}{l}n=107 \\
\text { during maintenance }\end{array}$ & None & $\begin{array}{l}\text { In UC median } 4.2 \mu \mathrm{g} / \mathrm{mL}(\mathrm{IQR}=2.4-9.477) \text { and in } \\
\text { Crohn } 5.9(\mathrm{IQR}=3.9-12.65) \\
\text { in suboptimal response }(n=38 ; 35.5 \%) \text { median } \\
1.8 \mu \mathrm{g} / \mathrm{mL} \text { (range } 0.04-3.4)\end{array}$ \\
\hline
\end{tabular}

IBDU, unclassified inflammatory bowel disease; IQR, interquartile range; UC, ulcerative colitis.

patient group (41). The therapeutic outcome in the young patients, however, was not different from the older patients $(24,41)$. However, it is not just weight or age of the patients that have an impact on the trough levels and the outcome of the therapy. The level of inflammation as reflected in the levels of albumin and inflammatory markers is a key player in drug pharmacokinetics (42). Therefore, in patients with high inflammatory load, higher dosing of infliximab is needed to reach 
target levels $(3,5)$. Disappointingly, a recent report stated that although trough levels during induction therapy with infliximab increased and antibody formation decreased, the proportion of pediatric patients maintaining their therapeutic response during the first year did not increase (20). It is not clear why some patients with trough levels considered as adequate, lose their therapeutic response. As this may occur after several months of maintenance therapy, it has been suggested that in these late nonresponders the inflammatory pathway is altered and becomes resistant to TNF $\alpha$ blockade $(43,44)$. Indeed, the initial response to infliximab therapy during induction is predictive for the longterm outcome of the therapy both in children and in adults with IBD. Patients with low levels of fecal calprotectin at the end of induction are more likely to have a favorable long-term outcome compared to patients with elevated levels of fecal calprotectin reflecting ongoing inflammation after induction $(7,45)$.

\section{Is Determination of Drug Antibodies Necessary?}

There are several different tests for the detection of drug antibodies, each having different levels of detection and cutoffs for a raised value. In most assays, the level of infliximab interferes with the test performance and the result is negative when there is measurable infliximab in the blood (32). When drug levels are undetectable, the risk of antibody formation is increased and thus, a rapid therapy escalation is needed. In clinical practice, this most often includes shortening of the interval and increasing the dose (e.g., $(10,41))$. However, when trough levels of the drug are well within the target range, the impact of measurable drug antibodies is less likely to be of clinical importance. Notably, drug antibodies may appear already during induction $(18,46)$ although in most cases they are detected during maintenance at the time of secondary loss of response (32). In the single-center report by Cohen and coauthors, drug antibodies with a detection limit of $3.1 \mathrm{U} / \mathrm{mL}$ for infliximab were present in one fourth of the anti-TNF $\alpha$ treated patients (47). They concluded that therapy optimization rather than switching to another therapeutic agent is advisable with antibody level $<10 \mathrm{U} / \mathrm{mL}$. In several reports, it has been suggested that high antibody titers carry a risk for antibodyrelated adverse events, e.g., serum sickness type antigen-antibody reaction, but the definition of such a high level of antibodies is inconclusive. The pharmacokinetics, pharmacodynamics, and immunogenicity of infliximab in PIBD was recently comprehensively reviewed (12). Taken together, there is no need

\section{REFERENCES}

1. Aardoom MA, Veereman G, de Ridder L. A review on the use of anti-TNF in children and adolescents with inflammatory bowel disease. Int J Mol Sci. (2019) 20:2529. doi: 10.3390/ijms20102529

2. de Ridder L, Assa A, Bronsky J, Romano C, Russell RK, Afzal NA, et al. Use of biosimilars in pediatric inflammatory bowel disease: an updated position statement of the pediatric iBD porto group of eSPGHAN. J Pediatr Gastroenterol Nutr. (2019) 68:144-153. doi: 10.1097/MPG.00000000000 02141 to measure drug antibodies when trough levels are within the therapeutic range but when trough levels are undetectable, drug antibody measurement is recommended and if the antibody titer is exceedingly high, it is advisable to discontinue the drug therapy.

\section{CONCLUSIONS}

Therapeutic drug monitoring of infliximab is here to stay for clinical decision-making. Patient age, weight and severity of the disease are important contributors to be taken into consideration when adjusting the therapy. Currently, trough levels above 3$5 \mathrm{mg} / \mathrm{mL}$ are considered adequate but in fistulazing disease target levels may be higher ( $\sim 10 \mathrm{mg} / \mathrm{mL}$ or more). An active infliximab trough monitoring strategy should be implemented with automatic measurement of drug antibodies in low trough levels. With such practice, patients with incomplete therapeutic response will have timely escalation of the therapy and possibly less drug antibody formation. When trough levels are within the target range, the determination of drug antibodies does not have clinical significance. With low trough levels and detectable drug antibodies, therapy enhancement may result in disappearance of the drug antibodies. However, with high titers of drug antibodies (the absolute values depending on the assay used), there is a risk for adverse antigen-antibody reactions and therapy should be discontinued at physician's discretion. When efficacy is not sufficient and trough levels are high, such patients are candidates for switching to another therapeutic agent. It seems that proactive therapeutic drug monitoring does not remarkably increase the proportion of patients having a long-term response to infliximab therapy but it aids in the recognition of the drug non-responders and therefore has the potential to result in a more cost-effective therapy.

\section{AUTHOR CONTRIBUTIONS}

K-LK conceptualization, interpretation of data, and writing original draft.

\section{FUNDING}

Pediatric Research Foundation (Finland) and Helsinki University Hospital Research Fund have provided study support for an ongoing research project on pediatric inflammatory bowel disease. 
5. Turner D, Ruemmele FM, Orlanski-Meyer E, Griffiths AM, de Carpi JM, Bronsky J, et al. Management of paediatric ulcerative colitis, part 2: acute severe colitis-an evidence-based consensus guideline from the european crohn's and colitis organization and the european society of paediatric gastroenterology, hepatology and nutrition. J Pediatr Gastroenterol Nutr. (2018) 67:292-310. doi: 10.1097/MPG.0000000000002036

6. De Bie CI, Hummel TZ, Kindermann A, Kokke FT, Damen GM, Kneepkens $\mathrm{CM}$, et al. The duration of effect of infliximab maintenance treatment in paediatric Crohn's disease is limited. Aliment Pharmacol Ther. (2011) 33:24350. doi: $10.1111 / j .1365-2036.2010 .04507 . x$

7. Kolho KL, Sipponen T. The long-term outcome of anti-tumor necrosis factor$\alpha$ therapy related to fecal calprotectin values during induction therapy in pediatric inflammatory bowel disease. Scand J Gastroenterol. (2014) 49:43441. doi: $10.3109 / 00365521.2014 .886719$

8. Topf-Olivestone C, Turner D. How effective is the use of long-term anti-TNF for paediatric iBD? Clues from real-life surveillance cohorts. Arch Dis Child. (2015) 100:391-2. doi: 10.1136/archdischild-2014-3 06467

9. Vande Casteele N, Ferrante M, Van Assche G, Ballet V, Compernolle G, Van Steen $\mathrm{K}$ et al. Trough concentrations of infliximab guide dosing for patients with inflammatory bowel disease. Gastroenterology. (2015) 148:13209.e3. doi: 10.1053/j.gastro.2015.02.031

10. Joosse ME, Samsom JN, van der Woude CJ, Escher JC, van Gelder T. The role of therapeutic drug monitoring of anti-Tumor necrosis factor alpha agents in children and adolescents with inflammatory bowel disease. Inflamm Bowel Dis. (2015) 21:2214-21. doi: 10.1097/MIB.00000000000 00420

11. Papamichael K, Cheifetz AS, Melmed GY, Irving PM, Vande Casteele N, Kozuch PL, et al. Appropriate therapeutic drug monitoring of biologic agents for patients with inflammatory bowel diseases. Clin Gastroenterol Hepatol. (2019) 17:1655-68.e3. doi: 10.1016/j.cgh.2019.03.037

12. Winter DA, Joosse ME, de Wildt SN, Taminiau J, de Ridder L, Escher JC. Pharmacokinetics, pharmacodynamics, and immunogenicity of infliximab in pediatric inflammatory bowel disease: a Systematic review and revised dosing considerations. J Pediatr Gastroenterol Nutr. (2020) 70:76376. doi: 10.1097/MPG.0000000000002631

13. Sipponen T, Kolho KL. Fecal calprotectin in diagnosis and clinical assessment of inflammatory bowel disease. Scand J Gastroenterol. (2015) 50:7480. doi: 10.3109/00365521.2014.987809

14. Colman RJ, Tsai YT, Jackson K, Boyle BM, Noe JD, Hyams JS, et al. Achieving target infliximab drug concentrations improves blood and fecal neutrophil biomarkers in Crohn's disease. Inflamm Bowel Dis. (2020). doi: 10.1093/ibd/izaa241. [Epub ahead of print].

15. Haas L, Chevalier R, Major BT, Enders F, Kumar S, Tung J. Biologic agents are associated with excessive weight gain in children with inflammatory bowel disease. Dig Dis Sci. (2017) 62:3110-6. doi: 10.1007/s10620-0174745-1

16. Lepp J, Höög C, Forsell A, Fyrhake U, Lördal M, Almer S. Rapid weight gain in infliximab treated Crohn's disease patients is sustained over time: real-life data over 12 months. Scand J Gastroenterol. (2020) 55:141118. doi: 10.1080/00365521.2020.1837929

17. Hämäläinen A, Sipponen T, Kolho KL. Infliximab in pediatric inflammatory bowel disease rapidly decreases fecal calprotectin levels. World J Gastroenterol. (2011) 17:5166-71. doi: 10.3748/wjg.v17.i47.5166

18. Hämäläinen A, Sipponen T, Kolho KL. Serum infliximab concentrations in pediatric inflammatory bowel disease. Scand J Gastroenterol. (2013) 48:3541. doi: 10.3109/00365521.2012.741619

19. Merras-Salmio L, Kolho KL. Clinical use of infliximab trough levels and antibodies to infliximab in pediatric patients with inflammatory bowel disease. J Pediatr Gastroenterol Nutr. (2017) 64:272-8. doi: 10.1097/MPG.0000000000001258

20. Nikkonen A, Kolho KL. Infliximab and its biosimilar produced similar firstyear therapy outcomes in patients with inflammatory bowel disease. Acta Paediatr. (2020) 109:836-41. doi: 10.1111/apa.15026

21. Guidi L, Pugliese D, Tonucci TP, Berrino A, Tolusso B, Basile M, et al. Therapeutic drug monitoring is more cost-Effective than a clinically based approach in the management of loss of response to infliximab in inflammatory bowel disease: an observational multicentre study. J Crohns Colitis. (2018) 12:1079-88. doi: 10.1093/ecco-jcc/jjy076
22. Wren AA, Park KT. Targeted dosing as a precision health approach to pharmacotherapy in children with inflammatory bowel disease. AMA J Ethics. (2018) 20:E841-8. doi: 10.1001/amajethics.2018.841

23. Naviglio S, Lacorte D, Lucafò M, Cifù A, Favretto D, Cuzzoni E, et al. Causes of treatment failure in children with inflammatory bowel disease treated with infliximab: a Pharmacokinetic study. J Pediatr Gastroenterol Nutr. (2019) 68:37-44. doi: 10.1097/MPG.0000000000002112

24. Lega S, Phan BL, Rosenthal CJ, Gordon J, Haddad N, Pittman N, et al. Proactively optimized infliximab monotherapy is as effective as combination therapy in iBD. Inflamm Bowel Dis. (2019) 25:134-41. doi: 10.1093/ibd/izy203

25. Clarkston K, Tsai YT, Jackson K, Rosen MJ, Denson LA, Minar P. Development of infliximab target concentrations during induction in pediatric Crohn disease patients. J Pediatr Gastroenterol Nutr. (2019) 69:6874. doi: 10.1097/MPG.0000000000002304

26. van Hoeve K, Dreesen E, Hoffman I, Van Assche G, Ferrante M, Gils A, et al. Adequate infliximab exposure during induction predicts remission in paediatric patients with inflammatory bowel disease. J Pediatr Gastroenterol Nutr. (2019) 68:847-53. doi: 10.1097/MPG.0000000000002265

27. van Hoeve K, Dreesen E, Hoffman I, Van Assche G, Ferrante M, Gils A, et al. Higher infliximab trough levels are associated with better outcome in paediatric patients with inflammatory bowel disease. J Crohns Colitis. (2018) 12:1316-25. doi: $10.1093 /$ ecco-jcc/jjyl11

28. Ungar B, Glidai Y, Yavzori M, Picard O, Fudim E, Lahad A, et al. Association between infliximab drug and antibody levels and therapy outcome in pediatric inflammatory bowel diseases. J Pediatr Gastroenterol Nutr. (2018) 67:50712. doi: 10.1097/MPG.0000000000002051

29. Choi SY, Kang B, Choe YH. Serum infliximab cutoff trough level values for maintaining hematological remission in pediatric inflammatory bowel disease. Gut Liver. (2019) 13:541-8. doi: 10.5009/gnl18129

30. Rolandsdotter H, Marits P, Sundin U, Wikström AC, Fagerberg UL, Finkel Y, et al. Serum-Infliximab trough levels in 45 children with inflammatory bowel disease on maintenance treatment. Int J Mol Sci. (2017) 18:575. doi: 10.3390/ijms18030575

31. Deora V, Kozak J, El-Kalla M, Huynh HQ, El-Matary W. Therapeutic drug monitoring was helpful in guiding the decision-making process for children receiving infliximab for inflammatory bowel disease. Acta Paediatr. (2017) 106:1863-7. doi: 10.1111/apa.14008

32. Chaparro M, Guerra I, Muñoz-Linares P, Gisbert JP. Systematic review: antibodies and anti-TNF- $\alpha$ levels in inflammatory bowel disease. Aliment Pharmacol Ther. (2012) 35:971-86. doi: 10.1111/j.1365-2036.2012.05057.x

33. Hofmekler T, Bertha M, McCracken C, Martineau B, McKinnon E, Schoen BT, et al. Infliximab optimization based on therapeutic drug monitoring in pediatric inflammatory bowel disease. J Pediatr Gastroenterol Nutr. (2017) 64:580-5. doi: 10.1097/MPG.0000000000001302

34. El-Matary W, Walters TD, Huynh HQ, deBruyn J, Mack DR, Jacobson K, et al. Higher postinduction infliximab serum trough levels are associated with healing of fistulizing perianal crohn's disease in children. Inflamm Bowel Dis. (2019) 25:150-5. doi: 10.1093/ibd/izy217

35. Greener T, Kabakchiev B, Steinhart AH, Silverberg MS. Higher infliximab levels are not associated with an increase in adverse events in inflammatory bowel disease. Inflamm Bowel Dis. (2018) 24:1808-14. doi: 10.1093/ibd/izy066

36. Papamichail K, Clarke WT, Casteele NV, Germansky KA, Feuerstein JD, Melmed GY, et al. Comparison of assays for therapeutic monitoring of infliximab and adalimumab in patients with inflammatory bowel diseases. Clin Gastroenterol Hepatol. (2020). doi: 10.1016/j.cgh.2020.03.002. [Epub ahead of print].

37. Ungar B, Chowers Y, Yavzori M, Picard O, Fudim E, Har-Noy O, et al. The temporal evolution of antidrug antibodies in patients with inflammatory bowel disease treated with infliximab. Gut. (2014) 63:125864. doi: 10.1136/gutjnl-2013-305259

38. Adedokun OJ, Xu Z, Padgett L, Blank M, Johanns J, Griffiths A, et al. Pharmacokinetics of infliximab in children with moderate-to-severe ulcerative colitis: results from a randomized, multicenter, open-label, phase 3 study. Inflamm Bowel Dis. (2013) 19:2753-62. doi: 10.1097/01.MIB.0000435438.84365.f7

39. Dubinsky MC, Phan BL, Singh N, Rabizadeh S, Mould DR. Pharmacokinetic dashboard-Recommended dosing is different than standard of care dosing in infliximab-Treated pediatric iBD patients. AAPS J. (2017) 19:21522. doi: 10.1208/s12248-016-9994-y 
40. Kirchgesner J, Lemaitre M, Carrat F, Zureik M, Carbonnel F, DraySpira R. Risk of serious and opportunistic infections associated with treatment of inflammatory bowel diseases. Gastroenterology. (2018) 155:33746.e10. doi: 10.1053/j.gastro.2018.04.012

41. Jongsma MME, Winter DA, Huynh HQ, Norsa L, Hussey S, Kolho KL, et al. Infliximab in young paediatric iBD patients: it is all about the dosing. Eur J Pediatr. (2020) 179:1935-44. doi: 10.1007/s00431-020-03750-0

42. Bauman LE, Xiong Y, Mizuno T, Minar P, Fukuda T, Dong M, et al. Improved population pharmacokinetic model for predicting optimized infliximab exposure in pediatric inflammatory bowel disease. Inflamm Bowel Dis. (2020) 26:429-39. doi: 10.1093/ibd/izz143

43. Fernandes C, Allocca M, Danese S, Fiorino G. Progress with antitumor necrosis factor therapeutics for the treatment of inflammatory bowel disease. Immunotherapy. (2015) 7:175-90. doi: 10.2217/imt. 14.105

44. Roblin X, Vérot C, Paul S, Duru G, Williet N, Boschetti G, et al. Is the pharmacokinetic profile of a first anti-TNF predictive of the clinical outcome and pharmacokinetics of a second anti-TNF? Inflamm Bowel Dis. (2018) 24:2078-85. doi: 10.1093/ibd/izy111

45. Molander P, af Björkesten CG, Mustonen H, Haapamäki J, Vauhkonen $\mathrm{M}$, Kolho KL, et al. Fecal calprotectin concentration predicts outcome in inflammatory bowel disease after induction therapy with TNF $\alpha$ blocking agents. Inflamm Bowel Dis. (2012) 18:2011-7. doi: 10.1002/ibd.22863

46. Bar-Yoseph H, Levhar N, Selinger L, Manor U, Yavzori M, Picard O, et al. Early drug and anti-infliximab antibody levels for prediction of primary nonresponse to infliximab therapy. Aliment Pharmacol Ther. (2018) 47:2128. doi: 10.1111/apt.14410

47. Cohen RZ, Schoen BT, Kugathasan S, Sauer CG. Management of anti-drug antibodies to biologic medications in children with inflammatory bowel disease. J Pediatr Gastroenterol Nutr. (2019) 69:551-6. doi: 10.1097/MPG.0000000000002440

Conflict of Interest: The author declares that the research was conducted in the absence of any commercial or financial relationships that could be construed as a potential conflict of interest.

Copyright (c) 2021 Kolho. This is an open-access article distributed under the terms of the Creative Commons Attribution License (CC BY). The use, distribution or reproduction in other forums is permitted, provided the original author(s) and the copyright owner(s) are credited and that the original publication in this journal is cited, in accordance with accepted academic practice. No use, distribution or reproduction is permitted which does not comply with these terms. 